\title{
Risk and protection factors in the peer context: how do other children contribute to the psychosocial adjustment of the adolescent?
}

\author{
Fatores de risco e proteção no contexto dos pares: como outras \\ crianças contribuem para o ajuste psicossocial do adolescente?
}

Marie-Hélène Véronneau ${ }^{1}$ Sophie-Caroline Trempe ${ }^{1}$ Alexandra Oliveira Paiva ${ }^{1}$
${ }^{1}$ Département de Psychologie, Faculté des Sciences Humaines, Université du Québec à Montréal. succ. 8888 succursale Centre-Ville Montréal QC H3C 3P8 Canada. veronneau.mariehelene@uqam.ca
Abstract As children become adolescents, peers assume greater importance in their lives. Peer experiences can either help them thrive or negatively affect their psychosocial adjustment. In this review article definitions for the types of peer experiences are provided followed by an overview of common psychosocial issues encountered by adolescents. Past research that has pointed to risk and protection factors that emerge from peer experiences during adolescence and the role of peer influences in the context of current issues relevant to adolescent education are discussed. Research suggests that friendships with deviant peers, involvement in bullying and the experience of rejection from the overall peer group are related to adjustment problems, whereas friendships with prosocial and academically oriented peers and social acceptance in the peer group are related to healthy development. Friendship quality, popularity among peers, and involvement in friendship cliques cannot be clearly categorized as either positive or negative influences, because they interact with other factors in shaping the development of adolescents. The promotion of social skills and positive youth leadership as an integral part of the student's learning process in school is recommended.

Key words Peer relationships, Protection factors, Risk factors, Development of the adolescent
Resumo No momento que as crianças se tornam adolescentes, colegas assumem uma importância maior em suas vidas. Experiências com os colegas podem ajudá-los a prosperar ou, ao contrário, prejudicar o seu ajustamento psicossocial. Este artigo de revisão primeiro fornece definições para os tipos de experiências entre pares, em seguida dá uma visão geral das principais questões psicossociais enfrentadas pelos adolescentes e, finalmente, analisa pesquisas anteriores que apontaram risco e fatores de proteção emergentes das experiências entre pares durante a adolescência. A pesquisa sugere que as amizades com pares desviantes, envolvimento em atos de bullying, e a experiência da rejeição do grupo global de pares são relacionados com problemas de adaptação, enquanto amizades com colegas pró-sociais, orientação acadêmica e aceitação social do grupo de pares são relacionadas com um desenvolvimento saudável. Amizade de qualidade, popularidade entre os pares e envolvimento em panelinhas de amizade não podem ser claramente classificados como influências positivas ou negativas, porque interagem com outros fatores na formação do desenvolvimento dos adolescentes.

Palavras-chave Relações entre pares, Fatores de proteção, Fatores de risco, Desenvolvimento do adolescente 


\section{Introduction}

When one thinks about vulnerability and resiliency in the context of human development, strengths and weaknesses at the individual level first come to mind. In practice, most intervention programs designed to prevent adverse outcomes, such as depression, anxiety, and substance use, focus on individual factors ${ }^{1-3}$. However, the combination of resiliency and vulnerability factors that makes each individual unique cannot be fully understood outside of the social context in which they live and grow. There is growing evidence that human development is driven by interactions between individual and environmental factors ${ }^{4}$. In this article we provide an overview of one important but often neglected source of social influence in adolescent adjustment: peer experiences. Adult influences of family, teachers, coaches, and mentors are obviously important in youth development ${ }^{5-7}$. But as children grow older, peers become increasingly important in youths' cognitive, social, and emotional development ${ }^{8,9}$. Researchers and practitioners must strive to understand the many ways in which peers may play the roles of risk and protective factors, so that policies and interventions aimed at building youths' resiliency take into account all major sources of social influence.

The goal of this article is to highlight some of the theoretical work that has contributed to give a coherent framework to interpret the many studies conducted on peer relationships. Also, the empirical studies that are described in this article were selected because they provide good examples of current trends in this field of research. In this review, we first define the peer experiences that are most commonly studied and briefly describe aspects of psychosocial adjustment that can be influenced by peers. We then explain how certain types of peer experiences may increase youths' vulnerability for maladjustment and how others can enhance their resilience.

\section{Defining Peer Experiences}

Peers are individuals who share some relative equity with regard to age, power status within the society at large, and social contexts that they occupy daily (e.g., schools, neighborhoods, parks, online social networks). Rubin et al. ${ }^{10}$ suggest a useful framework to describe different levels of social complexity in peer experiences. Two individuals interacting on a regular basis develop a dyadic relationship (e.g., friendship, antipathy, romance, partnership in sports), but social experiences in the larger group experiences are more complex. Peer groups are particularly relevant to the life of Western adolescents because almost all youths attend school with their age mates. Social norms, pressures, and hierarchies that influence adolescents' social experiences emerge in large part from the peer group itself. In the same way that adults have informal leaders, so do teenagers.It is nearly impossible to capture the full range of cumulative and multiplicative complexity across the several levels of social hierarchy. Nevertheless, deeper understanding of these processes can emerge from studies in which results are contextualized and other elements of adolescents' social life are taken into account.

\section{Friendships}

Because friendships have received more research attention than have other types of dyadic experiences, our review focuses on their influence on adolescent adjustment. It is generally agreed that friendships are voluntary and reciprocated and that their purpose is to satisfy socioaffective needs (e.g., love, attachment, affection, intimacy, loyalty, support, security) rather than to serve exclusively instrumental need ${ }^{10-12}$. Conflicts, disagreements, or fights may arise between friends, but they are not predominant - otherwise, the friendship is usually terminated. In their meta-analysis, Newcomb and Bagwell ${ }^{13}$ note that many studies have looked at unilateral friendships, which suggests that reciprocity of the relationship is not always considered to be an essential criterion of friendship. These authors suggest the use of two axes, knowing and liking, to classify peer relationships; as such, mutual friends would rate highly on both axes.

According to Hartup ${ }^{14}$, three friendship dimensions contribute to adolescent adjustment. The first dimension is the mere presence of friends. Social isolation or friendlessness might bring about the kind of negative consequences that friended adolescents are likely to avoid. Yet, the possible occurrence of negative pressures from deviant friends raises the question: Are some youths better off friendless than having deviant friends? From this perspective, Hartup's second dimension - the characteristics of one's friends (their "identity") - is relevant. Beyond the presence and characteristics of friends, this author proposed one last dimension: friendship quality. Many aspects of friends' interactions influence 
the extent to which a friendship can fulfill adolescents' socioaffective needs. Bukowski et al. ${ }^{15}$ identified five qualities of friendships: companionship, conflict, help/aid, security, and closeness.Just as having friends does not guarantee more positive outcomes than being friendless, high quality friendships do not always contribute to youth adjustment, because friendship quality may strengthen the influence of maladjusted peers.

\section{Small-group Dynamics}

Bullying. Smith et al. ${ }^{16}$ defined bullying as intentional and repetitive aggressive behavior from one person that causes harm to a vulnerable peer. Bullies may engage in physical, verbal, or relational (social) aggression. Female bullies are more likely to use social aggression (rejection, isolation), whereas male bullies more often use physical aggression ${ }^{17,18}$. Bullying is not a merely dyadic phenomenon; bystanders also have important roles to play in this social dynamic. Bystanders can be assistants and reinforcers of the bully, defenders of the victim, or simply passive ${ }^{19}$. Individual and peer group characteristics influence the likelihood that bystanders willor will not intervene in favor of the victim ${ }^{10,20}$.

Cliques. Individuals who get along and who share similar attributes tend to coalesce in small, informal groups of peers whom they interact with frequently and whom they know well. These groups are known as friendship cliques $^{21}$. They include about three to 10 individuals, often with different hierarchical statuses (e.g., leaders, peripheral members). In turn, each clique has a specific status in the broader peer group ${ }^{22}$. In early adolescence, cliques are relatively exclusive and most often segregated by gender. They are a major context of socialization until middle to late adolescence, when they become more inclusive, heterosexual, and looser, and then eventually dissolve, leaving room for relationships that are more adaptive to the social demands of emerging adults ${ }^{23}$.

\section{Status in the Larger Peer Group}

A major distinction between dyadic or smallgroup versus large-group dynamics is the amount of control that youths have over these phenomena. Friendships and small-group experiences arise from interpersonal interactions that afford more direct control. In larger networks, perceptions, opinions, and feelings that individuals have about other members can be based on information obtained indirectly rather than through direct interactions. It can be difficult for students to change their social status or reputation, which can be distressing if one believes that others' perceptions of oneself are negative or if these perceptions are the basis for unwanted interactions, such as bullying.

Sociometric assessments of children's and adolescents' feelings toward their peers have been available for a long time ${ }^{24}$. There exist two main dimensions of social perception: social preference, that is, the group's overall positive or negative feelings toward an individual and social impact, that is, the salience of the individual within the peer group ${ }^{25,26}$. Social preference is computed as the difference between like-most and like-least peer nominations, whereas social impact is based on the total number of peer nominations. Highimpact individuals are either popular (high levels of liking by peers), rejected (high levels of disliking), or controversial (high levels of both liking and disliking). Average-impact youths are positively appraised by their peers, but their social impact is moderate. Neglected individuals have a low social impact and are rarely nominated by their peers, so they are neither clearly liked nor disliked.

Because the meaning of the word popular for many adolescents is tied to social power and dominance rather than to positive feelings of group members toward an individual ${ }^{27}$, today's researchers usually use terms such as social acceptance or sociometric popularity when referring to amount of peer liking, whereas perceived popularity (or simply popularity) is usually used to refer to peers' perception of an individual's social influence and dominance in the peer group ${ }^{28}$.

\section{Common Issues in Child and Adolescent Psychosocial Adjustment}

During adolescence, many psychosocial issues may arise and be influenced by youths' positive and negative experiences with their peers. One type of difficulty is externalizing problems, which, according to the Diagnostic and Statistical Manual of Mental Disorders (DSM) ${ }^{29}$, include attention-deficit, disruptive, and aggressive behaviors. Many adverse consequences can result from these disorders, including delinquency, substance use, school maladjustment, and depression ${ }^{30-32}$.

Another family of disorders includes internalizing problems, which are more likely than externalizing issues to go unnoticed, because af- 
fected individuals experience them as internal distress. These problems include anxiety, depression, withdrawal, somatic complaints, and affective disorder ${ }^{29}$. In their review, Ollendick and King ${ }^{33}$ noted that internalizing problems are frequent in childhood and adolescence, are often comorbid with behavior problems, and may continue until adulthood. Marcotte et al. ${ }^{34}$ found that depressive symptoms are a stronger predictor of school dropout than are externalizing problems.

Substance use is also a rising concern as children become adolescents. The use of many substances can lead to dependence and abuse, including alcohol, amphetamine, cannabis, hallucinogens, cocaine, nicotine, opiates, and others ${ }^{29}$. Other substance-induced disorders include intoxication or withdrawal problems. Risks associated with substance use include risky sexual behavior, property or violent crimes, depression, suicidal ideation, school maladjustment, and suicide attempts ${ }^{35-37}$. Substance use problems often co-occur with externalizing problems as part of a more general syndrome of rule-breaking or impulsive behavior, or with internalizing problems, because substances are sometimes used as self-medication by individuals experiencing depression or anxiety ${ }^{38}$.

Schooling is also an important aspect of youth psychosocial adjustment because it contributes to the development of knowledge and abilities needed to succeed in the job market, to reach a better quality of life, and to remain healthier during adulthood ${ }^{39,40}$. Academic adjustment consists of outcomes such as school persistence, academic achievement, and school engagement.

\section{Risk and Protective Factors Emerging From the Peer Context}

\section{Friendlessness and social isolation}

Friendless adolescents experience more emotional distress than do their friended counterparts $^{41-43}$. Friendlessness is associated with social and academic problems, including disruptiveness, low academic performance, and fewer prosocial behaviors ${ }^{42,43}$. Although friendlessness can be initially caused by social and behavioral difficulties, being deprived of regular and positive interactions with a well-adapted friend can aggravate these psychosocial issues. Nevertheless, social withdrawal can protect against substance use, because access to social situations that encourage it is limited ${ }^{4,45}$.

\section{Friend influences}

Even if youth adjustment issues initially develop from a combination of individual and family risk factors, affiliation with friends who engage in deviant activities (e.g., substance use, delinquency, school dropout) may further contribute to children's and adolescents' maladjustment, including externalizing, delinquent, and violent behaviors ${ }^{46-48}$; promiscuous sexual behavior ${ }^{49}$; and substance use ${ }^{50,51}$. Possible mechanisms include engagement in coercive behaviors and mutual reinforcement of attitudes in favor of deviant behavior through interaction with maladjusted peers ${ }^{52}$. Friends' deviant behaviors are also associated with adolescents' academic maladjustment $^{53,54}$ and depressive symptoms ${ }^{47,55}$.

In contrast, reviews conducted by Berndt ${ }^{11,56}$ suggest that positive friendships-for example, those with friends who enact prosocial behavior, those with a high level of intimacy, and those with a low level of conflict-are associated with better outcomes with regard to adolescents' social skills, stress management, and school adjustment. Positive qualities of the relationship with one's best friends may protect adolescents against social anxiety, internalizing problems, and externalizing problems $s^{57,58}$. Friendships characterized by companionship and recreation, validation and caring, help and guidance, intimate disclosure, low conflict and betrayal, and positive conflict resolution contribute to youths' global self-worth, self-esteem, and peer acceptance ${ }^{12,58}$. Positive friendships can also protect against peer victimization ${ }^{59}$. Adolescents' academic adjustment can be influenced by friends' grades and values ${ }^{60,61}$.

Because high-quality relationships tend to strengthen friends' influence, this aspect of friendship is not always protective in that it can foster problem behavior, such as substance use, if it involves deviant friends ${ }^{62}$. Furthermore, even though closeness and intimacy are usually positive friendship features, they sometimes contribute to adolescents' depressive symptoms and aggressive behavior ${ }^{63,64}$. The underlying mechanism appears to be engagement in corumination, wherein friends discuss, revisit, speculate about, and focus on problems and negative feelings ${ }^{65}$.

\section{Small-group processes}

In line with findings related to friendships, the impact of small-group processes depends on group members' characteristics. Salmivalli et al. ${ }^{19}$ showed that adolescents' bullying behavior was 
more strongly predicted by their friendship group's characteristics than by their own traits ${ }^{66}$. Weapon carrying and relational aggression tend to increase as a result of friendship group influences ${ }^{67,68}$. In addition, college students who are exposed to school dropouts through their social network are more likely to drop out of school as well ${ }^{69}$.

Tobacco use behavior appears to influence friendship selection to a greater degree than it is learned from the group ${ }^{70,71}$. Nevertheless, teenagers' smoking may be an imitation of the behavior observed in a clique that one wants to join, which can be an indirect form of peer influence $^{70,72}$. In contrast, alcohol use tends to increase after joining a peer group in which this behavior is normative $e^{63,73}$.

Small-group processes can also reinforce positive outcomes. According to Ryan ${ }^{74}$, school adjustment can be socialized within friendship groups. Barber et al. ${ }^{75}$ suggest that by engaging in extracurricular activities, adolescents can develop a positive identity and healthy behaviors by learning positive norms from the peer group they integrate; however, some extracurricular sports may involve exposure to risky behavior.

Belonging to a friendship clique can be more risky for boys than for girls. If clique membership protects young adolescents against internalizing symptoms, it also facilitates the emergence of externalizing behavior among boys ${ }^{76}$. Similarly, peer group membership is related to positive behavioral, academic, and social outcomes for girls, but not for boys.

Bullying is one specific type of small-group dynamics that is particularly concerning for all parties involved. Bullies, victims, and bully-victims experience health, emotional, social, and academic problems ${ }^{77}$. Bullies are more likely to carry weapons and use alcohol; victims experience poorer relationships with classmates, loneliness, low self-worth, and academic maladjustment $^{78,79}$. Solberg and Olweus ${ }^{80}$ found that victimization may affect other areas of peer experiences, including feelings of social acceptance and belonging, and it predicts negative self-evaluation and depressive symptoms.

\section{Social status in the larger peer group}

Results from many studies that included measurement of peer rejection, externalizing problems, and academic maladjustment suggest that these three areas of adjustment are interrelat- $\mathrm{ed}^{81,82}$. One explanation is that aggressive adolescents are at higher risk of becoming rejected, and peer rejection precipitates academic failure ${ }^{83}$. Peer rejection is also linked to substance use by late adolescence as part of a developmental cascade that involves parenting issues and deviant peer affiliations $^{84,85}$. Outcomes of social exclusion can be quite different depending on individuals. For example, exclusion can increase symptoms of depression and anxiety in some adolescents ${ }^{82,85}$. One possible mechanism could be that negative peer involvement increases self-doubt and decreases self-esteem ${ }^{86}$.

On the opposite end of the social status spectrum are adolescents who experience high levels of social acceptance; these youths are rated as well adjusted by their classmates and teachers ${ }^{81}$. For those adolescents who have a negative relationship with their parents, peer acceptance can protect against drops in self-esteem ${ }^{87}$; it can also protect against friends' encouragement to use alcohol or to engage in delinquent behavior ${ }^{88}$. Peer acceptance is associated with less loneliness and greater academic achievement ${ }^{89}$. Because accepted students receive more support, develop better social skills, and have a greater sense of belonging to the school, they more often experience positive outcomes ${ }^{90}$.

Whereas the picture tends to be generally positive for socially accepted students, perceived popularity in the peer group has been linked to mixed outcomes, probably because popular teenagers are especially sensitive to inductive peer norms that they need to follow to maintain a high social status. When these norms are deviant, it can lead to problem behavior. Popularity has been linked to risks of substance use, sexual activity, and academic problems ${ }^{91-93}$. Popular adolescents are likely to engage in direct and indirect aggression and in rule-breaking behaviors (substance use, minor delinquency) to maintain their social status ${ }^{94,95}$. Popular adolescents exhibit higher levels of externalizing problems, and popular boys present fewer internalizing problems-perhaps because they value dominance, and being popular makes them feel successful ${ }^{96}$. Nevertheless, popular adolescents have access to a wider range of socialization experiences, which can contribute to enhancing their understanding of others and of social situations". Subgroups of "highstatus" and "well-liked" preadolescents who are very socially skilled ${ }^{97}$ could play an important role in the peer group through positive leadership. 


\section{Discussion}

Peer influences do not occur in a vacuum. Governmental and school-specific regulations that influence school structures, academic curricula, and the composition of the student population may contribute to influencing students' peer experiences to become either risk or protective factors. To illustrate this argument, we present a few examples from the Québec school system.

\section{Peer influences in the context of the Québec school reform}

In the 1990s, the Québec Ministry of Education initiated a reform of the education system, and since 2001 significant pedagogical changes have been implemented in elementary and secondary schools ${ }^{98}$. The main goal of the reform was to strengthen students' ability to develop applied skills and their overall level of academic success $^{99}$. This reform was in large part inspired by a socio-constructivist educational approach, which emphasizes the development of cross-curricular skills and autonomous learning ${ }^{100}$. Although this reform has been questioned and criticized by many ${ }^{101}$, we argue that at least one positive consequence of the new pedagogical strategy is worth considering, that is, its likely contribution to the improvement of students' peer experiences and social skills.

According to the socio-constructivist approach, learning is a social and interpersonal process; therefore, collaborative peer interactions under the supervision and guidance of a teacher can promote not only the construction of knowledge, as intended by the new program, but also the development of students' social skills ${ }^{100}$. Teamwork promoting collaboration instead of competition or exclusion is an example of what socio-constructivism puts forward. Our goal here is not to take a position for or against the reform of Québec's education system. Instead, we encourage decision makers and school administrators around the world to consider the value of purposefully integrating activities within the academic curriculum that will contribute to developing a positive school climate and to strengthening children's and adolescents' social skills. Such improvements should be explicitly considered when assessing the quality and outcomes of academic curricula.

\section{Accessibility to private schools in Québec} and its impact on peer group composition

Another example from the Québec educational system is students' easier access to private schools and the impact of this situation on the student body composition in various schools. The government of Québec financially supports about $50 \%$ of private education, making it affordable for a large number of families to send their children to private schools rather than public schools ${ }^{102}$. Private schools offer interesting academic achievement opportunities and as such, they compete aggressively with public schools ${ }^{103}$. The result is that less money is allocated per student in public schools, which ultimately may negatively affect student performance. In addition, because middle-class parents can afford to send their students to private schools, and because private schools do not tend to have many students with learning disabilities ${ }^{104}$, public schools are faced with the task of educating a particularly disadvantaged and at-risk student population, especially in urban settings ${ }^{105}$. This is quite problematic in light of results from empirical studies that have shown that classmates' socioeconomic status influences student achievement more than their own status does ${ }^{106}$. We suggest that contagion of potentially harmful social norms among public school students who may have lower academic ambitions than their peers from a wealthier, more educated background could be one of the mechanisms explaining such findings. Decision makers should therefore be aware that political choices that influence the composition of student populations in various schools can create gaps in the quality of the learning environment offered to students from lower versus middle to higher social classes. The resulting disparity in academic gains made by students from the two systems is probably not entirely due to differences in financial or human resources in the schools - it is likely influenced by lack of access to positive peer influences in public schools.

The last point of discussion is more universal and optimistic: We suggest that positive peer leaders can play the role of protective factors in the context of any geographical region, school curricula, or school type. The existence of natural leaders within adolescent peer groups is a notion that makes sense theoretically ${ }^{107}$, and it is supported by empirical research ${ }^{26}$. Positive social in- 
fluence is likely to be quite efficient when channelled through existing peer leaders, and several programs have successfully promoted adolescent physical health (less drug use, better nutrition, less risky behavior in relation to HIV transmission) by using peer leaders to spread positive norms and behaviors ${ }^{108-110}$. Interestingly, Valente et al. ${ }^{111}$ found that peer-led programs are especially efficient when they are guided by youths who are identified through social network analysis as peer leaders in the program. Nevertheless, a more recent study suggested that using peer leaders to discourage substance use may be counterproductive when targeting adolescents who are exposed to deviant peer norms about substance use $^{112}$. Mixed findings have also emerged with regard to outcomes of a peer-led antibullying program ${ }^{113}$. Peer-led programs are promising, but they should be carefully monitored for potentially iatrogenic effects before they are scaled up and disseminated to other milieus.

\section{Conclusion: Summary and Implications}

Peer experiences in adolescence are quite heterogeneous. In the context of friendship, large-group processes, or small-group dynamics, both protective and risk factors can emerge. Peer experiences within and across various levels of social complexity are likely to interact; thus, when one looks at a single aspect of an adolescent's social experience, it is difficult to predict whether he or she is at risk for maladjustment. Adults who work with youths may help protect them against negative peer influences by reinforcing respectful and prosocial behaviors in natural settings, such as the context of collaborative learning in the classroom. If negative peer influences often reinforce issues that emerged from problematic family dynamics, peers can also play a protective role when positive norms and values are reinforced by the peer group as a whole and by positive peer leaders in particular.

\section{Collaborations}

The relative contribution to this article by the three authors (MH Véronneau, SC Trempe, and A Oliveira Paiva) is reflected by the authorship order, with the first author contributing the most.

\section{Acknowledgments}

The authors wish to acknowledge the work of Marie-Pier Dupré for her help with the literature review and of Rhea Marshall-Denton and Cheryl Mikkola for their help with formatting and editing the manuscript. 


\section{References}

1. Neil AL, Christensen H. Efficacy and effectiveness of school-based prevention and early intervention programs for anxiety. Clinical Psychology Review 2009; 29(3):208-215.

2. Calear AL, Christensen H. Systematic review of school-based prevention and early intervention programs for depression. Journal of Adolescence 2010; 33(3):429-438.

3. Teesson M, Newton NC, Barrett EL. Australian school-based prevention programs for alcohol and other drugs: A systematic review. Drug and Alcohol Review 2012; 31(6):731-736.

4. Bronfenbrenner U, Morris PA. The bioecological model of human development. In: Lerner RM, Damon W, organizadores. Handbook of child psychology: Vol 1 Theoretical models of human development. New York: Wiley; 2006. p. 793-828.

5. Pomerantz EM, Kim EM, Cheung CS-S. Parents' involvement in children' learning. APA educational psychology handbook, Vol 2: Individual differences and cultural and contextual factors. In: Harris KR, Graham S, Urdan T, Royer JM, Zeidner M, organizadores. Washington: American Psychological Association; 2012. p. 417-440.

6. Wayne AJ, Youngs P. Teacher characteristics and student achievement gains: A review. Review of Educational Research 2003; 73(1):89-122.

7. Farmer TW, Lines MM, Hamm JV. Revealing the invisible hand: The role of teachers in children's peer experiences. Journal of Applied Dev Psychol 2011; 32(5):247-256.

8. Lynch M, Cicchetti D. Children's relationships with adults and peers: An examination of elementary and junior high school students. Journal of School Psychology 1997; 35(1):81-99.

9. Furman W, Buhrmester D. Age and sex differences in perceptions of networks of personal relationships. Child Development 1992; 63(1):103-115.

10. Rubin KH, Bukowski WM, Parker JG. Peer interactions, relationships, and groups. In: Damon W, Lerner RM, Eisenberg N, organizadores. Handbook of child psychology: Vol 3 Social, emotional, and personality development. New York: Wiley; 2006. p. 571-645.

11. Berndt TJ. Friendship and friends' influence in adolescence. Current Directions in Psychological Science 1992; 1(5):156-159.

12. Keefe K, Berndt TJ. Relations of friendship quality to self-esteem in early adolescence. J Early Adolesc 1996; 16(1):110-129.

13. Newcomb AF, Bagwell CL. Children's friendship relations: A meta-analytic review. Psychological Bulletin 1995; 117(2):306-347.

14. Hartup WW. The company they keep: Friendships and their developmental significance. Child Development 1996; 67(1):1-13.

15. Bukowski WM, Hoza B, Boivin M. Measuring friendship quality during pre- and early adolescence: The development and psychometric properties of the friendship qualities scale. Journal of Social and Personal Relationships 1994; 11(3):471-484.
16. Smith P, Morita Y, Junger-Tas J, Olweus D, Catalano RF, Slee P. The nature of school bullying: $A$ cross-national perspective. London: Taylor \& Frances/ Routledge; 1999.

17. Craig WM. The relationship among bullying, victimization, depression, anxiety, and aggression in elementary school children. Personality and Individual Differences 1998; 24(1):123-130.

18. Crick NR, Bigbee MA. Relational and overt forms of peer victimization: A multiinformant approach. J Consult Clin Psychol 1998; 66(2):337-347.

19. Salmivalli C, Lagerspetz K, Björkqvist K, Österman $\mathrm{K}$, Kaukiainen A. Bullying as a group process: Participant roles and their relations to social status within the group. Aggressive Behavior 1996; 22(1):1-15.

20. Pozzoli T, Gini G, Vieno A. The role of individual correlates and class norms in defending and passive bystanding behavior in bullying: A multilevel analysis. Child Development 2012; 83(6):1917-1931.

21. Brown BB. Peer groups and peer cultures. In: Feldman SS, Elliott GR, organizadores. At the threshold: The developing adolescent. Cambridge: Harvard University Press; 1990. p. 171-196.

22. Crockett L, Losoff M, Petersen AC. Perceptions of the peer group and friendship in early adolescence. J Early Adolesc 1984; 4(2):155-181.

23. Shrum W, Cheek NH. Social structure during the school years: Onset of the degrouping process. American Sociological Review 1987; 52(2):218-223.

24. Moreno JL. Who shall survive? A new approach to the problem of human interrelations. Washington: Nervous and Mental Disease Pub. Co.; 1934.

25. Newcomb AF, Bukowski WM. Social impact and social preference as determinants of children's peer group status. Dev Psychol 1983; 19(6):856-867.

26. Coie JD, Dodge KA, Coppotelli H. Dimensions and types of social status: A cross-age perspective. Dev Psychol 1982; 18(4):557-570.

27. Parkhurst JT, Hopmeyer A. Sociometric popularity and peer-perceived popularity: Two distinct dimensions of peer status. J Early Adolesc 1998; 18(2):125144.

28. Mayeux L, Houser JJ, Dyches KD. Social acceptance and popularity: Two distinct forms of peer status. In: Cillessen AHN, Schwartz D, Mayeux L, organizadores. Popularity in the peer system. New York: Guilford Press; 2011. p. 79-102.

29. American Psychiatric Association. Diagnostic and statistical manual of mental disorders. $4^{\text {th }}$ Edition. Arlington: American Psychiatric Association; 2000.

30. Loeber R, Stouthamer-Loeber M, Raskin White H. Developmental aspects of delinquency and internalizing problems and their association with persistent juvenile substance use between ages 7 and 18. J Clin Child Psychol 1999; 28(3):322-332.

31. Hinshaw SP. Externalizing behavior problems and academic underachievement in childhood and adolescence: Causal relationships and underlying mechanisms. Psychological Bulletin 1992; 111(1):127-155. 
32. Kosterman R, Hawkins JD, Mason WA, Herrenkohl TI, Lengua LJ, McCauley E. Assessment of behavior problems in childhood and adolescence as predictors of early adult depression. Journal of Psychopathology and Behavioral Assessment 2010; 32(1):118127.

33. Ollendick TH, King NJ. Diagnosis, assessment, and treatment of internalizing problems in children: The role of longitudinal data. J Consult Clin Psychol 1994; 62(5):918-927.

34. Marcotte D, Fortin L, Royer É, Potvin P, Leclerc D. L'influence du style parental, de la dépression et des troubles du comportement sur le risque d'abandon scolaire. Revue des sciences de l'éducation 2001; 27(3):687.

35. Lowry R, Holtzman D, Truman BI, Kann L, Collins JL, Kolbe LJ. Substance use and HIV-related sexual behaviors among US high school students: Are they related? Am J Public Health 1994; 84(7):1116-1120.

36. Fergusson DM, Horwood LJ, Swain-Campbell N. Cannabis use and psychosocial adjustment in adolescence and young adulthood. Addiction 2002; 97(9):1123-1135.

37. Gosselin C, Larocque D, Vitaro F, Gagnon C. Identification des facteurs liés à la consommation de cigarettes, d'alcool et de drogues à l'adolescence [Identification of the factors linked to cigarette, alcohol and drug use in adolescence]. International Journal of Psychology 2000; 35(1):46-59.

38. Compton WM, Thomas YF, Stinson FS, Grant BF. Prevalence, correlates, disability, and comorbidity of DSM-IV drug abuse and dependence in the United States: Results from the National Epidemiologic Survey on Alcohol and Related Conditions. Archives of General Psychiatry 2007; 64(5):566-576.

39. Lapostolle L. Réussite scolaire et réussite éducative: quelques repères [School and academic success: A timeline]. Pédagogie collégiale 2006; 19(4):5-7.

40. Adams SJ. Educational attainment and health: Evidence from a sample of older adults. Education Economics 2002; 10(1):97-109.

41. Bukowski WM, Laursen B, Hoza B. The snowball effect: Friendship moderates escalations in depressed affect among avoidant and excluded children. Dev Psychopathol 2010; 22(4):749-757.

42. Wentzel KR, Barry CM, Caldwell KA. Friendships in middle school: Influences on motivation and school adjustment. Journal of Educational Psychology 2004; 96(2):195-203.

43. Vitaro F, Brendgen M, Wanner B. Patterns of affiliation with delinquent friends during late childhood and early adolescence: Correlates and consequences. Social Development 2005; 14(1):82-108.

44. Myers MG, Aarons GA, Tomlinson K, Stein MB. Social anxiety, negative affectivity, and substance use among high school students. Psychology of Addict Behav 2003; 14(4):277-283.

45. Fergusson DM, Horwood LJ. Prospective childhood predictors of deviant peer affiliations in adolescence. J Child Psychol Psychiatry 1999; 40(4):581-592.
46. Reitz E, Dekovic M, Meijer AM, Engels RCME. Longitudinal relations among parenting, best friends, and early adolescent problem behavior: Testing bidirectional effects. J Early Adolesc 2006; 26(3):272295.

47. Brendgen M, Vitaro F, Bukowski WM. Deviant friends and early adolescents' emotional and behavioral adjustment. Journal of Research on Adolescence 2000; 10(2):173-189.

48. Dishion TJ, Véronneau M-H, Myers MW. Cascading peer dynamics underlying the progression from problem behavior to violence in early to late adolescence. Dev Psychopathol 2010; 22(3):603-619.

49. Dishion TJ, Ha T, Véronneau M-H. An ecological analysis of the effects of deviant peer clustering on sexual promiscuity, problem behavior, and childbearing from early adolescence to adulthood: An enhancement of the life history framework. Dev Psychol 2012; 48(3):703-717.

50. Connell AM, Dishion TJ, Deater-Deckard K. Variable - and person-centered approaches to the analysis of early adolescent substance use: Linking peer, family, and intervention effects with developmental trajectories. Merrill-Palmer Quarterly 2006; 52(3): 421-448.

51. Dishion TJ, Medici Skaggs N. An ecological analysis of monthly "bursts" in early adolescent substance use. Applied Developmental Science 2000; 4(2):89-97.

52. Dishion TJ, Andrews DW, Crosby L. Antisocial boys and their friends in early adolescence: Relationship characteristics, quality, and interactional process. Child Development 1995; 66(1):139-151.

53. Li Y, Lynch AD, Kalvin C, Liu J, Lerner RM. Peer relationships as a context for the development of school engagement during early adolescence. International Journal of Behavioral Development 2011; 35(4):329-342.

54. Véronneau M-H, Dishion TJ. Middle school friendships and academic achievement in early adolescence: A longitudinal analysis. J Early Adolesc 2011; 31(1):99-124

55. Connell AM, Dishion TJ. The contribution of peers to monthly variation in adolescent depressed mood: A short-term longitudinal study with time-varying predictors. Dev Psychopathol 2006; 18(1):139-154.

56. Berndt TJ. Friendship quality and social development. Current Directions in Psychological Science 2002; 11(1):7-10.

57. La Greca AM, Harrison HM. Adolescent peer relations, friendships, and romantic relationships: Do they predict social anxiety and depression? J Clin Child Adolesc Psychol 2005; 34(1):49-61.

58. Rubin KH, Coplan RJ. Paying attention to and not neglecting social withdrawal and social isolation. Merrill-Palmer Quarterly 2004; 50(4):506-534.

59. Criss MM, Pettit GS, Bates JE, Dodge KA, Lapp AL. Family adversity, positive peer relationships, and children's externalizing behavior: A longitudinal perspective on risk and resilience. Child Development 2002; 73(4):1220-1237. 
60. Holland NE. The power of peers: Influences on postsecondary education planning and experiences of African American students. Urban Education 2011; 46(5):1029-1055.

61. Altermatt ER, Pomerantz EM. The implications of having high-achieving versus low-achieving friends: A longitudinal analysis. Social Development 2005; 14(1):61-81.

62. Urberg KA, Luo Q, Pilgrim C, Degirmencioglu SM. A two-stage model of peer influence in adolescent substance use: Individual and relationship-specific differences in susceptibility to influence. Addict Behav 2003; 28(7):1243-1256.

63. Giletta M, Scholte R, Prinstein M, Engels R, Rabaglietti E, Burk W. Friendship context matters: Examining the domain specificity of alcohol and depression socialization among adolescents. $J A b$ norm Child Psychol 2012; 40(7):1027-1043.

64. Tompkins TL, Hockett AR, Abraibesh N, Witt JL. A closer look at co-rumination: Gender, coping, peer functioning and internalizing/externalizing problems. Journal of Adolescence 2011; 34(5):801-811.

65. Rose AJ. Co-rumination in the friendships of girls and boys. Child Development 2002; 73(6):1830-1843.

66. Espelage DL, Holt MK, Henkel RR. Examination of peer-group contextual effects on aggression during early adolescence. Child Development 2003; 74(1): 205-220.

67. Dijkstra JK, Gest SD, Lindenberg S, Veenstra R, Cillessen AHN. Testing three explanations of the emergence of weapon carrying in peer context: The roles of aggression, victimization, and the social network. J Adolesc Health 2012; 50(4):371-376.

68. Dijkstra JK, Berger C, Lindenberg S. Do physical and relational aggression explain adolescents' friendship selection? The competing roles of network characteristics, gender, and social status. $A g$ gressive behavior 2011; 37(5):417-429.

69. Eckles J, Stradley E. A social network analysis of student retention using archival data. Social Psychology of Education 2012; 15(2):165-180.

70. Ennett ST, Bauman KE. Peer group structure and adolescent cigarette smoking: A social network analysis. J Health Soc Behav 1993; 34(3):226-236.

71. DeLay D, Laursen B, Kiuru N, Nurmi J-E, SalmelaAro K. Selecting and retaining friends on the basis of cigarette smoking similarity. Journal of Research on Adolescence 2013; 23(3):464-473.

72. Pearson M, Michell L. Smoke rings: Social network analysis of friendship groups, smoking and drugtaking. Drugs: Education, Prevention \& Policy 2000; 7(1):21-37.

73. Burk WJ, Van der Vorst H, Kerr M, Stattin Hk. Alcohol use and friendship dynamics: Selection and socialization in early-, middle-, and late-adolescent peer networks. J Stud Alcohol Drugs 2012; 73(1): 89-98.

74. Ryan AM. The peer group as a context for the development of young adolescent motivation and achievement. Child Development 2001; 72(4):11351150 .
75. Barber BL, Stone MR, Hunt JE, Eccles JS. Benefits of activity participation: The roles of identity affirmation and peer group norm sharing. In: Mahoney JL, Larson RW, Eccles JS, organizadores. Organized activities as contexts of development: Extracurricular activities, after-school and community programs. Mahwah: Lawrence Erlbaum; 2005. p. 185-210.

76. Witvliet M, van Lier PAC, Brendgen M, Koot HM, Vitaro F. Longitudinal associations between clique membership status and internalizing and externalizing problems during late childhood. J Clin Child Adolesc Psychol 2010; 39(5):693-704.

77. Henrich CC, Kuperminc GP, Sack A, Blatt SJ, Leadbeater BJ. Characteristics and homogeneity of early adolescent friendship groups: A comparison of male and female clique and nonclique members. Applied Developmental Science 2000; 4(1):15-26.

78. Nansel TR, Craig W, Overpeck MD, Saluja G, Ruan W. Cross-national consistency in the relationship between bullying behaviors and psychosocial adjustment. Archives of Pediatrics and Adolescent Medicine 2004; 158(8):730-736.

79. Juvonen J, Nishina A, Graham S. Peer harassment, psychological adjustment, and school functioning in early adolescence. Journal of Educational Psychology 2000; 92(2):349-359.

80. Solberg ME, Olweus D. Prevalence estimation of school bullying with the Olweus Bully/Victim Questionnaire. Aggressive Behavior 2003; 29(3):239-268.

81. Wentzel KR, Asher SR. The academic lives of neglected, rejected, popular, and controversial children. Child Development 1995; 66(3):754-763.

82. Fite PJ, Wimsatt AR, Vitulano ML, Rathert JL, Schwartz S. Examination of peer rejection and depressive symptoms as mediators of the link between rule-breaking behavior and poor academic performance. Journal of Psychopathology and Behavioral Assessment 2012; 34(2):164-171.

83. Dodge KA, Malone PS, Lansford JE, Miller S, Pettit GS, Bates JE. A dynamic cascade model of the development of substance-use onset. Monographs of the Society for Research in Child Development 2009; 74(3):vii-119.

84. Van Ryzin MJ, Fosco GM, Dishion TJ. Family and peer predictors of substance use from early adolescence to early adulthood: An 11-year prospective analysis. Addict Behav 2012; 37(12):1314-1324.

85. Coplan RJ, Rose-Krasnor L, Weeks M, Kingsbury A. Alone is a crowd: Social motivations, social withdrawal, and socioemotional functioning in later childhood. Dev Psychol 2013; 49(5):861-875.

86. Inderbitzen HM, Walters KS, Bukowski AL. The role of social anxiety in adolescent peer relations: Differences among sociometric status groups and rejected subgroups. J Clin Child Psychol 2010; 26(4):338-348.

87. Birkeland MS, Breivik K, Wold B. Peer acceptance protects global self-esteem from negative effects of low closeness to parents during ddolescence and early adulthood. J Youth Adolesc. In press 2013. 
88. Laursen B, Hafen CA, Kerr M, Stattin HK. Friend influence over adolescent problem behaviors as a function of relative peer acceptance: To be liked is to be emulated. Journal of Abnormal Psychology 2012; 121(1):88-94.

89. Newman JK, Erdley CA, Marshall KC. Peer aceptance and friendship as predictors of early adolescents' adjustment across the middle school transition. Merrill-Palmer Quarterly 2011; 57(3):215-243.

90. Wentzel KR. Peers and academic functioning at school. In: Rubin KH, Bukowski WM, Laursen B, organizadores. Handbook of peer interactions, relationships, and groups. Guilford Press: New York; 2009. p. 531-547.

91. Mayeux L, Sandstrom MJ, Cillessen AHN. Is being popular a risky proposition? Journal of Research on Adolescence 2008; 18(1):49-74.

92. Troop-Gordon W, Visconti KJ, Kuntz KJ. Perceived popularity during early adolescence: Links to declining school adjustment among aggressive youth. J Early Adolesc 2011; 31(125):765-785.

93. Schwartz D, Gorman AH, Nakamoto J, McKay T. Popularity, social acceptance, and aggression in adolescent peer groups: Links with academic performance and school attendance. Dev Psychol 2006; 42(6):1116-1127.

94. Allen PJ, Porter MF, McFarlan FC, Marsh P, McElhaney KB. The two faces of adolescents' success with peers: Adolescent popularity, social adaptation, and deviant behavior. Child Development 2005; 76(3):747-760.

95. Rose AJ, Swenson LP, Carlson W. Friendships of aggressive youth: Considering the influences of being disliked and of being perceived as popular. $J$ Exp Child Psychol 2004; 88(1):25-45.

96. Sandstrom MJ, Cillessen A. Likeable versus popular: Distinct implications for adolescent adjustment. International Journal of Behavioral Development 2006; 30(4):305-314.

97. Lease AM, Musgrove KT, Axelrod JL. Dimensions of social status in preadolescent peer groups: Likability, perceived popularity, and social dominance. Social Development 2002; 11(4):508-533.

98. Guimont G. La réforme de l'éducation et le renouveau pédagogique au Québec: Les faits saillants. Pédagogie Collégiale 2009; 22(3):29-34.

99. Inchauspé P, Beaulieu M, Berger J-P, Lalonde C, Derome J-R, Levy C, Vachon P. Réaffirmer l'école: Rapport du groupe de travail sur la réforme du curriculum. Québec: Ministère de l'éducation; 1997.

100. Lafortune L, Deaudelin C. Accompagnement socioconstructiviste: Pour s'approprier une réforme en éducation. Montréal: Presses de l'Université du Québec; 2001.

101. Boutin G, Julien L. L'obsession des compétences: Son impact sur l'école et la formation des enseignants. Montréal: Éditions Nouvelles; 2000.
102. Bernier S. Le choix de l'école pour tous: Un projet de bons d'étude adapté au Québec. Montréal: Montreal Institute of Economics; 2003.

103. Andersen SC, Serritzlew S. The unintended effects of private school competition. Journal of Public Administration Research and Theory 2007; 17(2): 335-356.

104. Caldas SJ, Bernier S. The effects of competition from private schooling on French public school districts in the province of Quebec. The Journal of Educational Research 2012; 105(5):353-365.

105. Milner H. Éducation et politique au Québec: L'adaptation des structures du XIXe siècle aux défis du XXIe siècle. In: Gagnon A-G, organizador. Québec: État et société. Tome I. Montréal: Les éditions Québec/Amérique; 1994. p. 383-404.

106. Caldas SJ, Bankston C. Effect of school population socioeconomic status on individual academic achievement. The Journal of Educational Research 1997; 90(5):269-277.

107. Hawley PH. The ontogenesis of social dominance: A strategy-based evolutionary perspective. Developmental Review 1999; 19(1):97-132.

108. Birnbaum AS, Lytle LA, Story M, Perry CL, Murray DM. Are differences in exposure to a multicomponent school-based intervention associated with varying dietary outcomes in adolescents? Health Education \& Behavior 2002; 29(4):427-443.

109. Cuijpers P. Effective ingredients of school-based drug prevention programs: A systematic review. Addict Behav 2002; 27(6):1009-1023.

110. Pearlman DN, Camberg L, Wallace LJ, Symons P, Finison L. Tapping youth as agents for change: Evaluation of a peer leadership HIV/AIDS intervention. J Adolesc Health 2002; 31(1):31-39.

111. Valente TW, Hoffman, BR, Ritt-Olsan, A, Lichtman, K, Johnson, CA. Effects of a social-network method for group assignment strategies on peerled tobacco prevention programs in schools. Am J Public Health 2003; 93(11):1837-1843.

112. Valente TW, Ritt-Olson, A, Stacy, A, Unger, JB, Okamoto, J, Sussman, S. Peer acceleration: Effects of a social network tailored substance abuse prevention program among high-risk adolescents. Addiction 2007; 102(11):1804-1815.

113. Salmivalli C. Peer-led intervention campaign against school bullying: Who considered it useful, who benefited? Educational Research 2001; 43(3):263-278.

Artigo apresentado em 25/09/2013

Aprovado em 17/11/2013

Versão final apresentada em 27/11/2013 